\title{
Establishing Evaluation Index Systems of Product Selection in Online Group Buying
}

\author{
Ranzhe Jing \\ School of Information Management and Engineering \\ Shanghai University of Finance and economics \\ Shanghai, China, 200433 \\ e-mail: jing.ranzhe@mail.shufe.edu.cn
}

\begin{abstract}
With the rapid development of electronic business, many online group-buying websites emerged, these websites provide products or service to customers with a discount. What kinds of products can increase customer purchasing intentions still an austere fact in the face of competition for the managers of online group-buying firms. This study examines antecedents of online group-buying intention from a view of product selection, it focuses on how to select the most attractive product to evoke customers purchase intentions. The research model is based on technology acceptance model, social commerce, electronic word-ofmouth, and analytic hierarchy process method, and the analytical results demonstrate that search cost, product description, customer perception, and profitability are key factors influence online group-buying product selection.
\end{abstract}

Keywords-online group-buying; product selection; purchase intention; electronic word-of-mouth; analytic hierarchy process

\section{INTRODUCTION}

Being driven by the constantly pushing of network information technology, a new e-business mode-online group buying is spring up in recent years. It has successfully captured more and more consumers' attention. Group buying, also known as collective buying, offers products and services at significantly reduced prices on the condition that a minimum number of buyers would make the purchase. Origins of group buying can be traced to China where tuangou or team buying was executed to get discount prices from retailer when a large group of people were willing to buy the same item. In recent time, group buying websites have emerged as a major player in online shopping business [1]. Typically, these websites feature a "deal of the day", with the deal kicking in once a set number of people agree to buy the product or service. Buyers then print off a voucher to claim their discount at the retailer [2]. Many of the group-buying sites work by negotiating deals with local merchants and promising to deliver crowds in exchange for discounts. Recently, group buying has been taken online in numerous forms. By using online group buying, it is easy to find more people in a short period of time to share freight costs and to buy in bulk so as to lower prices [1]. It is also easier to get bigger discounts when more people take part in a group purchase.

The selection of which product to sell on group buying websites has become a challenge task to the manger. And it has also attracted many researchers to analyze the problem in the new e-business market.

\section{LITERATURE REVIEW}

Many factors are key determiners of online group buying behavior. Financial savings are often an important reason for individual organizations to join a purchasing group [3]. If these savings are realized, each of the members of the group should receive a fair part of the total savings [4].

Recently, some studies discussed that key factors influence consumer participation of online group-buying, including: motivation, trust, e-WOM, and reputation. Anand and Aron (2003) explored motivation of consumer participation in online group buying. They indicated price sensitivity, perceived risk, and conformity are the most significant factors that affect online group-buying [5]. According the importance of online customer, Jing (2011) indicated the degree of value consumers had influences online shopping [6]. Tsvetovat et al. (2000) identified online group-buying activity as comprising five stages: negotiation, coalition formation, initiator electing/voting, payment collection, and execution/distribution [7]. Tsai et al. (2011) examined the impact of technology acceptance factors and social factors on online group-buying. They indicated that perceived usefulness, a sense of virtual community and trust in the virtual community are determinants of intention. In addition, perceived ease of use and website quality influence perceived usefulness [8].

In today's virtual era, the power of word-of-mouth has grown exponentially. Viral marketing is associated with word-of-mouth through electronic media. Electronic wordof-mouth (eWOM) describes potential, current, or future consumers commenting positively or negatively regarding a store or product online [9]. Positive word-of-mouth supports a behavior or product. Picazo-Vela et al. (2010) defined subjective norm as the degree to which an individual perceives providing online reviews as a norm among people who are important to him or her. When reference groups keep posting similar comments (eWOM) on group-buying websites, they will form a high social norm. Thus, eWOM is a way of displaying subjective norm [10].

In an online environment, consumers rarely touch the product or recognize the eWOM sender. Source credibility is a vital predictor in the early stage when a consumer is choosing a Web site, and it contributes to the perceived credibility of messages on the site [11] [12]. Consumerperceived credibility of eWOM is defined as the extent to which one perceives a recommendation or review as believable, true, or factual [13]. Awad and Ragowsky 
(2008) suggested that perceived credibility is a prime determinant in a consumer's decision-making process, and reduces uncertainty in both social and business interactions [14].

E-WOM impact the consumer's adoption decision by influencing consumer perceptions of innovation attributes. The technology acceptance model is one highly influential approach to understanding the way perceived product attributes drive the adoption and use of innovative products. This model links user acceptance of new technology to consumer perceptions of innovation usefulness and ease of use.

Kawakami et al. (2013) extends the technology acceptance model by linking eWOM with consumer perceptions of product usefulness and ease of use [15]. Because adoption decisions are based on the total cost of innovation acquisition and use, decreases in the amount of effort required to use an innovation should increase the probability of adoption [16]

Kim et al. (2012) pointed out that social commerce is a new e-commerce mode to use innovative technologies and social media [17]. For consumers, social commerce can enhance the purchase experience, offering trust, utility and fun in key areas such as the discovery, selection and referral of products.

\section{COMPREHENSIVE EVALUATION INDEX SYSTEM}

\section{A. Feasibility of Product Online Sales}

The product per se has a significant influence on whether it should be transacted online or not. The following elements have something to do with product selection process: A1: Convenience to acquire the product and B1: Product identification.

We discuss A1 first. In traditional transaction mode, the more difficult the product to be gained, the more advantageous for consumers to purchase in online group buying. A1 can be further divided into four sub-indexes; A11: Satisfying special demands. The products such as nail clippers, combs which are common used could be easily found in supermarkets and could satisfy most people's demands, these products are difficult to be sold online. On the contrary, some products are aimed at customers with special purposes such as ancient money or stamps which could only satisfy special groups' requirements and hardly found in normal markets have obvious advantages on online transaction., To put it in another way, products which meet special groups' demands will enjoy competitive advantage over those ones with low application particularity in online group business. A12: Product richness, it refers to similar products with substantially huge quantities while each type of product can be precisely identified. In traditional transaction mode, consumers have to check the product one by one to find out the one they really want. It is really high time and energy cost. For example, if you go to a bookstore, there are thousands of books displayed on the shelves, which makes it difficult for consumers to find out a certain product quickly, thus resulting in relatively high cost to obtain. The situation is the same with shoes and drinks. On the contrary, consumers can easily find a product by using query function provided by online group buying website.
Apparently, the higher richness of a product is, the more favorable it is to sell the product in online group buying. A13: Richness of alternatives, it reflects the substitutability of different products belonging to the same class. Even some products have large numbers of quantities, they will be much easier to be obtained if they have multiple alternatives. For example, if you want to buy a pair of shoes, if you could not find the right one, you could swift to its alternatives, which is the similar brand and style. To some extent, it is acceptable and your shopping expectation is satisfied, and your cost is lowing. In conclusion, the richness of the product and their alternatives must be quite easy to be obtained in online group buying business. A14: Location and time limits. Some products such as regional and seasonal foods are highly restricted by time and locations, it is hard for a Chinese customer to get Singapore bak tea in normal markets, were this product to be sold online, it will be much easier meet customer's needs.

Now we talk about B1: Product identification demand, it refers to the degree to which a customer has to recognize and understand the product information from initial search ing to final purchase. It can be divided four sub-

indexes. B11: Product virtualization degree. The higher vir tualization degree of a product indicates easier identificatio $\mathrm{n}$ demand of a consumer, thus is more appropriate to be sol $\mathrm{d}$ in online group buying. Such products are mainly inform ation oriented ones involving film tickets, air ticket reserva tion and so forth. These kinds of products are easily to be sold via an Internet way because of its high level of virtuali zation. B12: Product standardization, it is one of the most important factors to judge the quality of a product. Under normal conditions, products with higher standardization are usually more trusted by customers in online transactions. B13: The degree of detail product information, the more detail information seller provided, the easier the product could be sold. Practice shows that physical product can be easier listed more information customer needs than service product and virtual product, as a conclusion, physical products are easier transacted online. B14: Easy to be described or shown. Online selling products should be described or shown clearly, only in this way can consumers fully understand its function or value. Shoes are easily sold online because they are easy to be seen by the consumers, such as the size, the color, the function, which are easily described and understood. So it a product is suitable to be sold online, it must be well described or shown in a clear way.

\section{B. Customer Purchase Intention Related Factors}

Customer purchase intention related factors mainly refer to those elements closely related to customer purchase experience and feelings during the whole process from he/she starts to purchase online to make ultimate buying decision, so here we call the factor $\mathrm{C} 1$ : Shopping experience needs. The lower shopping experience needs for the product are, the more suitable for the product to be sold online. The paper discusses it from four aspects; C11: Personal experience, some products entail high personal experience, like fashion dresses and special food. Consumers always determine to buy the product or not according to his/her personal experience after trying on the dress or foretasting the food. Consequently, a product in 
which shopping experience is highly needed to test consumers' satisfaction towards it isn't suitable to be sold online at all. C12: Ease of operation, if it is much easier to operate the product, then the shopping experience needs are lower as well, which enables the product to be sold online. Contrarily, those products like a suitcase calling for minutes to check its password reliability and safety is not advised to be online group buying products. C13: Product life cycle. The longer product life cycle demonstrates lower customer shopping experience needs, therefore, those types of product are suitable in online group buying. C14: Privacy. This index reflects to the consumer group who are not willing to purchase some products in traditional shops due to personal privacy, examples include drugs for special diseases, books containing special knowledge, etc. Therefore, the products indicating high personal privacy are ideal product type in online group buying.

\section{Characteristics of Online Group Buying}

The major or fundamental reason for websites to develop online group buying is that it is profitable and easy to copy. In online group buying, companies have to offer considerable discount to attract customers with remarkable fixed and variable costs like website design, advertising expenses, thus whether it is profitable or not is of crucial importance to online group buying websites. As a result, the product selection must be in accordance with online group buying own characteristics. The influencing factor sufficing to represent the characteristics is-D1: Product profitability. The more profitable the product is in online group buying, the more suitable it is to be sold online. It can be broken down into three sub-indexes; D11: Production scale, too small production scale will lead to low profit, which can hardly suffice to make up for the fixed costs, which leads to its inappropriateness in online group buying. For example, there is seldom aircraft production, so it is not good for selling on the Internet. D12: Profit margin, only if the profit margin is large, the expenses which spend on intermediate links could be reduced in online transaction. As a result, those electronic devices with relatively higher profit margin should be given high priority in online group buying product selection. D13: Product demand. The higher demand for a product indicates a considerably valuable opportunity to make money. Online group buying economy is a typical economic mode that entails high initial investment (fixed cost), and low subsequent cost (variable cost). As a result, it is of significantly importance to select a product with high market demand. The more people buy the products, the more profitable it is. The evaluation index system of product selection in online group buying is established as Table 1 .

\section{RESEARCH METHOD}

In order to test the evaluation index of product selection, this paper takes cosmetic of premium brand and fruit as an example, to check which one is much more suitable for online group buying.

The Analytic Hierarchy Process was proposed by a member of the National Academy of Engineering in USA, Professor Thomas L. Saaty at University of Pittsburgh. It is a simple, flexible and practical method for multiple criteria decision making.

TABLE I. EVALUATION INDEX SYSTEM OF PRODUCT SELECTION

\begin{tabular}{|c|c|}
\hline Index & Sub-index \\
\hline \multirow{4}{*}{$\begin{array}{l}\text { Convenience to acquire the } \\
\text { product } \\
\text { (A1) }\end{array}$} & Satisfying special demands (A11) \\
\hline & Product richness (A12) \\
\hline & Richness of alternatives (A13) \\
\hline & Location and time limits (A14) \\
\hline \multirow{4}{*}{$\begin{array}{l}\text { Product identification } \\
\text { demand } \\
\text { (B1) }\end{array}$} & Product virtualization degree (B11) \\
\hline & Product standardization (B12) \\
\hline & $\begin{array}{l}\text { The degree of detail product } \\
\text { information (B13) }\end{array}$ \\
\hline & $\begin{array}{l}\text { Easy to be described or shown } \\
\text { (B14) }\end{array}$ \\
\hline \multirow{4}{*}{$\begin{array}{l}\text { Customer experience needs } \\
\text { (C1) }\end{array}$} & $\begin{array}{l}\text { Previous purchase experience } \\
\text { (C11) }\end{array}$ \\
\hline & Complexity of the operation (C12) \\
\hline & Product life cycle (C13) \\
\hline & Privacy $(\mathrm{C} 14)$ \\
\hline \multirow{3}{*}{$\begin{array}{l}\text { Product profitability } \\
\text { (D1) }\end{array}$} & Production scale (D11) \\
\hline & Profit margin (D12) \\
\hline & Product demand (D13) \\
\hline
\end{tabular}

For each pairing within each criterion the better option is awarded a score, again, on a scale between 1 (equally good) and 9 (absolutely better), whilst the other option in the pairing is assigned a rating equal to the reciprocal of this value. Each score records how well option $\rightarrow$ " meets criterion $Y^{\prime}$. Afterwards, the ratings are normalized and averaged. Comparisons of elements in pairs require that they are homogeneous or close with respect to the common attribute; otherwise significant errors may be introduced into the process of measurement [18] [19]. Its algorithm is as follows:

Suppose $U=\left\{U_{1}, U_{2}, \ldots U_{n}\right\}$ is $n$ factors of the study, which is a key assessment of the object evaluation index, we called $U$ as an index set. $V=\left\{v_{1}, v_{2}, \ldots v_{\mathrm{m}}\right\}$ is $m$ kind posed by the judge evaluation set. The number of the evaluation set is according to the needs of practical problems identified by the decision makers subjective. Actually, most problems are fuzzy sets. So, the comprehensive evaluation is supposed a fuzzy subset.

$B=\left(b_{1}, b_{2}, \ldots b_{\mathrm{m}}\right) \in F(V)$ of $V, \mu_{\mathrm{B}}\left(v_{\mathrm{k}}\right)=b_{k}(k=1$, $2, \ldots, m)$. As a result, when power vector $W$ is given, corresponding to an integrated assessment for a given vector $B$.

Fuzzy comprehensive assessment of the general steps are as follows:

1) Determine the factors set $U=\left\{U_{1}, U_{2}, \ldots U_{n}\right\}$;

2) Determine the evaluation set $V=\left\{v_{1}, v_{2}, \ldots v_{m}\right\}$;

3) Determine the fuzzy evaluation matrix $R=\left(r_{i j}\right)_{n \times m}$;

Firstly, give each factor $U_{i}$ an evaluation $f\left(U_{i}\right)(i=1$, $2, \ldots, n)$, then we can get an fuzzy mapping $f$ from $U$ to $V$ :

$f: U \rightarrow F(U)$

$U_{i} \rightarrow F\left(U_{i}\right)=\left(r_{i 1}, r_{i 2}, \ldots, r_{i m}\right) \in f(V)$

Secondly, from $f$ we can induced the fuzzy relation $R_{f}$ $\in f(U \times V)$, $m)$
$R_{f}\left(U_{i}, V_{j}\right)=f\left(u_{i}\right)\left(v_{j}\right)=r_{i j}(i=1,2, \ldots, n ; j=1,2, \ldots$, 
we can determine the fuzzy evaluation $R=\left(r_{i j}\right)_{n \times m}$ called $(U, V, R)$ fuzzy comprehensive evalution model.

4) Comprehensive:

For weight $W=\left(W_{1}, W_{2}, W_{n}\right) \in F(U)$, According $M(\wedge, \vee)$, we can obtain the comprehensive evalution results.

$B=W \cdot R$

\section{A. Variable Metric}

As mentioned above, we study four variables: Convenience to acquire the product, Product identification demand, Customer experience needs and Product profitability with their own sub-variables respectively in this paper, A modified five point Likert scale ranging from strongly disagree (1), through neutral (3) to strongly agree (5) including the option of not-applicable" is used to design the questionnaire. The questions of part $\mathrm{D}$ is done by shops. The final question items are reported in Appendix A.

\section{B. Data Collection}

This study adopts survey research method, chooses consumers in a certain district in Shanghai as a sample. From May 2012 to June 2012, two hundred questionnaires are sent out in two batches. In the end, 300 questionnaires are recovered, 275 of which are valid, accounting for about $91.7 \%$. In all valid questionnaires, female consumers accounted for $68 \%$ of the total objects of the study, male consumers accounted for $32 \%$.

\section{DATA ANALYSIS}

In this study, the software called Expert Choice and SPSS17.0 is used for data analysis, given the factors such as the quantity of the sample, the complexity of the models, the convenience of accessing the software and so forth.

In order to test the reliability of the questions of the questionnaire, this study adopts Cronbach $\alpha$ to test the consistency level of each variable. The $\alpha$ values between each measured variables are shown as Table 2. All $\alpha$ values in Table 2 are greater than 0.75 , which is in accordance with the requirements.

TABLE II. CRONBACH A TEST OF EVALUATION INDEX

\begin{tabular}{|c|c|c|}
\hline Index & Sub-index & Cronbach $\alpha$ \\
\hline \multirow{4}{*}{$\begin{array}{l}\text { Convenience to acquire the product } \\
\text { (A1) }\end{array}$} & (A11) & \multirow{4}{*}{0.814} \\
\hline & (A12) & \\
\hline & (A13) & \\
\hline & (A14) & \\
\hline \multirow{4}{*}{$\begin{array}{l}\text { Product identification demand } \\
\text { (B1) }\end{array}$} & (B11) & \multirow{4}{*}{0.930} \\
\hline & (B12) & \\
\hline & (B13) & \\
\hline & (B14) & \\
\hline \multirow{4}{*}{$\begin{array}{l}\text { Customer experience needs } \\
\text { (C1) }\end{array}$} & (C11) & \multirow{4}{*}{0.865} \\
\hline & (C12) & \\
\hline & (C13) & \\
\hline & (C14) & \\
\hline \multirow{3}{*}{$\begin{array}{l}\text { Product profitability } \\
\text { (D1) }\end{array}$} & (D11) & \multirow{3}{*}{0.751} \\
\hline & (D12) & \\
\hline & (D13) & \\
\hline
\end{tabular}

We analyze the validity of the data with the help of KMO Test and Bartlett Test, results are shown as Table 3. According to the criteria proposed by Kaiser, KMO value should be no small than 0.8 , and has a good adaptability. It is suitable to do the factor analysis unless the significant probability of the factor value is smaller than 0.001 . In this experiment, this value of the probability is 0.000 , which means that it meets the test requirement.

TABLE III. KMO AND BARTLETT'S TEST

\begin{tabular}{|c|c|c|}
\hline Kaiser-Meyer-Olkin Measure of Sampling Adequacy & .895 \\
\hline \multirow{2}{*}{$\begin{array}{c}\text { Bartlett's Test of } \\
\text { Sphericity }\end{array}$} & Approx. Chi-Square & 3459.874 \\
\cline { 2 - 3 } & $\mathrm{df}$ & 136 \\
\cline { 2 - 3 } & Sig. & .000 \\
\hline
\end{tabular}

The study adopts AHP method to synthesize various influence factors and then make data analysis. And the results are shown as followings in Fig .1. The value of each CR is less than 0.1 , it means that the sample is consistent. From Fig .1 we can work out that the ideal degree of cosmetic of premium brand is 0.602 , and the ideal degree of fruit is 0.49 . So we can conclude that cosmetic of premium brand is much more suitable than fruit to be sold on the group buying website.

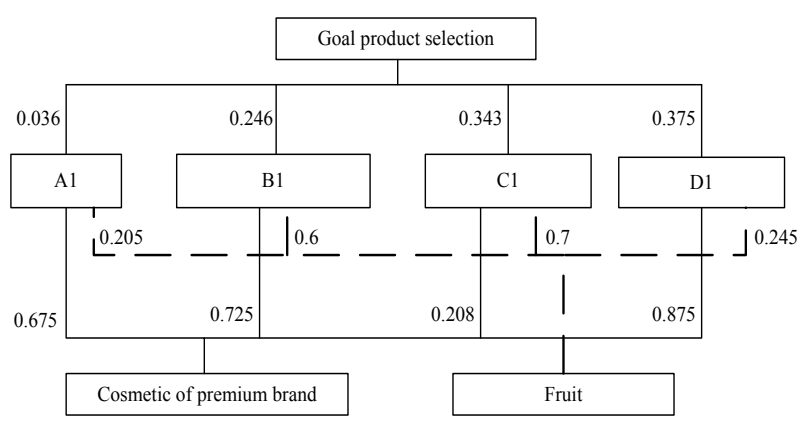

Figure 1. AHP method and weight

\section{CONCLUSIONS}

The theoretical significance of this study is to further discuss the production selection in online group buying business. First of all, this paper studies the factors which make the characters of products work, then proposes an evaluation index system to judge and select the online group buying products, and the content of every index discussed. Finally, the paper adopts AHP method to synthesize various influence factors and then make data analysis to offer online group buying firms practical advices. Research result indicates that consumers tend to purchase products with low search costs, low additional understanding demand, low shopping experience needs and high price discount. Those product types involve electronic products (laptops, cameras, etc), handbags, books, CDs, tickets, hats and apparels.

In this paper, we discuss comprehensively product selection influencing factors from three aspects-product attribute per se, online customer purchase intention as well as the specific characteristics of online group buying. Nevertheless, those factors may still be inadequate, which need further exploration in latter study. Other shortages 
need to be solved in this paper: first and foremost, due to practical place and time limitations, the survey sample is too small to be persuasive. The questionnaire design needs improvement as well in order to be better understood by respondents. Besides, the AHP method may not be the best analytical approach to process those data.

Despite of those limitations, the findings still have practical implications for the development of online group buying. Understanding product selection influencing factors can extend the customer knowledge of online group buying websites and lead to better business strategies. Our research provides a good threshold for online group buying websites seeking ways to improve profit margin in fierce market competition. Additional research will modify the influencing factors to further explore online group buying product selection in E-commerce.

\section{ACKNOWLEDGMENT}

The research is supported by the National Natural Science Foundation of China (NSFC Program No.71072037) and sponsored by Shanghai Pujiang Program.

\section{APPENDIX A: QUESTION ITEMS}

\begin{tabular}{|l|}
\hline $\begin{array}{l}\text { Cosmetic of premium brand and fruit, which one will you choose } \\
\text { to buy on the group buying website }\end{array}$ \\
\hline $\begin{array}{l}\text { 1. I think it is more easier to search cosmetic of premium brand than } \\
\text { fruit }\end{array}$ \\
\hline $\begin{array}{l}\text { 1.1 I think cosmetic of premium brand is much more particular than } \\
\text { fruit }\end{array}$ \\
\hline $\begin{array}{l}\text { 1.2 I think cosmetic of premium brand I need is much more rich than } \\
\text { fruit }\end{array}$ \\
\hline $\begin{array}{l}\text { 1.3 I think cosmetic of premium brand is much more distinctive than } \\
\text { fruit }\end{array}$ \\
\hline $\begin{array}{l}\text { 1.4 I think cosmetic of premium brand is much more regional or } \\
\text { seasonal than fruit }\end{array}$ \\
\hline $\begin{array}{l}\text { 2. I'd like to buy cosmetic of premium brand on the group buying } \\
\text { website because it need less identification demand than fruit }\end{array}$ \\
\hline $\begin{array}{l}\text { 2.1 I'd like to buy cosmetic of premium brand on the group buying } \\
\text { website because it is with higher visualization degree than fruit }\end{array}$ \\
\hline $\begin{array}{l}\text { 2.2 I'd like to buy cosmetic of premium brand on the group buying } \\
\text { website because it is with higher standardization than fruit }\end{array}$ \\
\hline $\begin{array}{l}\text { 2.3 I'd like to buy cosmetic of premium brand on the group buying } \\
\text { website because it is with higher product expressiveness than fruit }\end{array}$ \\
\hline $\begin{array}{l}\text { 2.4 I'd like to buy cosmetic of premium brand on the group buying } \\
\text { website because it can easily be described }\end{array}$ \\
\hline $\begin{array}{l}\text { 3. I think cosmetic of premium brand need less shopping experience } \\
\text { than fruit }\end{array}$ \\
\hline $\begin{array}{l}\text { 3.1 I'd like to buy cosmetic of premium brand on the group buying } \\
\text { website because it need lower personal experience than fruit }\end{array}$ \\
\hline $\begin{array}{l}\text { 3.2 I'd like to buy cosmetic of premium brand on the group buying } \\
\text { website because it is easier to operate on than fruit }\end{array}$ \\
\hline $\begin{array}{l}\text { 3.3 I'd like to buy cosmetic of premium brand on the group buying } \\
\text { website because it is with long life cycle than fruit }\end{array}$ \\
\hline $\begin{array}{l}\text { 3.4 I'd like to buy cosmetic of premium brand on the group buying } \\
\text { website because it needs higher privacy than fruit }\end{array}$ \\
\hline Cosmetic of premium brand and fruit, which one will you choose \\
\hline $\begin{array}{l}\text { 4.I think cosmetic of premium brand is much more profitable than } \\
\text { fruit }\end{array}$ \\
\hline $\begin{array}{l}\text { 4.1I think cosmetic of premium brand is with higher production scale } \\
\text { than fruit }\end{array}$ \\
\hline $\begin{array}{l}\text { 4.2 I think cosmetic of premium brand is with higher product margin } \\
\text { than fruit }\end{array}$ \\
\hline $\begin{array}{l}\text { 4.3 I think cosmetic of premium brand is much more needed than } \\
\text { rruit }\end{array}$ \\
\hline
\end{tabular}

\section{REFERENCES}

[1] Ranzhe Jing, Jingyang Wang. A review of research on online customer loyalty. WIT Transactions on Information and Communication Technologies. No. 4, 2013, pp. 1137-1144.

[2] Jincheng Wang, Ranzhe Jing. Exploring on the ways to improve online customer loyalty. International Conference on Logistics Informatics and Services Sciences. No. 2, 2011, pp. 38-46.

[3] Nollet, J., Beaulieu, M.. The development of group purchasing: An empirical study in the healthcare sector. Journal of Purchasing and Supply Management 9 (1), 2003, pp. 3-10.

[4] Dyer, J. H.. Collaborative advantage, winning through extended enterprise supplier networks. New York: Oxford University Press, 2000.

[5] Anand, K. S., \& Aron, R. Group buying on the web: A comparison of pricediscovery mechanisms. Management Science, 49(11), 2003, pp. $1546-1562$.

[6] Jing R. Z.. Online Customer Value Structure: a Network Analysis Approach. International Conference on Intelligent Systems and Knowledge Engineering. 2011, pp. 219-226.

[7] Tsvetovat, M., Sycara, K., Chen, Y., Ying, J.. Customer coalitions in the electronic marketplace. In Proceedings of the 3rd workshop on agent mediated electronic commerce. 2000, pp. 263-264.

[8] Tsai, M. T., Cheng, N. C., and Chen, K. S.. Understanding online group buying intention: The roles of sense of virtual community and technology acceptance factors. Total Quality Management \& Business Excellence, 22(10), 2011, pp. 1091-1104.

[9] Hennig-Thurau, T., Gwinner, K. P., Walsh, G., \& Gremler, D. D. Electronic word-of-mouth via consumer-opinion platforms: What motivates consumers to articulate themselves on the Internet? Journal of Interactive Marketing, 18(1), 2004, pp. 38-52.

[10] Picazo-Vela, S., Chou, S. Y., Melcher, A. J., \& Pearson, J. M. Why provide an online review? An extended theory of planned behavior and the role of Big-Five personality traits. Computers in Human Behavior, 26(4), 2010, pp. 685-696.

[11] Dabholkar, P. A.. Factors influencing consumer choice of a - iting web site": An experimental investigation of an online interactive decision aid. Journal of Marketing Theory and Practice, 14(4) 2006, pp. 259-273.

[12] Dou, X., Walden, J. A., Lee, S., \& Lee, J. Y.. Does source matter? Examining source effects in online product reviews. Computers in Human Behavior, 28(5), 2012, pp. 1555-1563.

[13] Cheung, M., Luo, C., Sia, C., and Chen, H.. Credibility of electronic word-of-mouth: Informational and normative determinants of on-line consumer recommendations. International Journal of Electronic Commerce, 13(4), 2009, pp. 9-38.

[14] Awad, N. F., \& Ragowsky, A.. Establishing trust in electronic commerce though online word of mouth: An examination across genders. Journal of Management Information Systems, 24(2), 2008, pp. 101-121.

[15] Tomoko Kawakami, Kazuhiro Kishiya, and Mark E. Parry Personal Word of Mouth, Virtual Word of Mouth, and Innovation Use. Journal of Product Innovation Management 2013;30(1), pp. 17-30.

[16] Song, M., M. E. Parry, and T. Kawakami. Incorporating network externalities into the technology adoption model. Journal of Product Innovation Management 26 (3): 2009, pp. 291-307.

[17] Kim S., M. Noh, K. Lee. Effects of antecedents of collectivism on consumers' intention to use social commerce. Journal of Applied Science. 12 (12), 2012, pp. 1265-1273.

[18] Saaty, T.L. How to make a decision: The Analytic Hierarchy Process. European Journal of Operational Research 48: 1990, pp. 9-26.

[19] Zahir, S.. Clusters in group: Decision making in the vector space formulation of the analytic hierarchy process. European Journal of Operational Research 112: 1999, pp. 620-634. 